\title{
Health of adolescent refugees resettling in high-income countries
}

\author{
Kajal Hirani, ${ }^{1,2}$ Donald Payne, ${ }^{1,2}$ Raewyn Mutch, ${ }^{3,4}$ Sarah Cherian ${ }^{2,4}$
}

\begin{abstract}
- Additional material is published online only. To view please visit the journal online (http://dx.doi.org/10.1136/ archdischild-2014-307221).

1 Department of Adolescent Medicine and Eating Disorders, Princess Margaret Hospital for Children, Perth, Western Australia, Australia

${ }^{2}$ School of Paediatrics and Child Health, University of Western Australia, Perth, Western Australia, Australia ${ }^{3}$ Telethon Kids Institute, Western Australia, Australia ${ }^{4}$ Refugee Health Service, Department of General Paediatrics, Princess Margaret Hospital for Children, Perth, Western Australia, Australia
\end{abstract}

\section{Correspondence to} Dr Sarah Cherian, Refugee Health Service, Department of General Paediatrics, Princess Margaret Hospital, Perth, WA 6008, Australia; sarah.cherian@health.wa.gov. $\mathrm{au}$

Received 24 June 2015 Revised 22 September 2015 Accepted 23 September 2015 Published Online First 15 October 2015

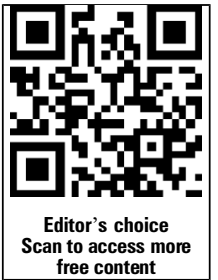

\section{ABSTRACT}

Adolescent refugees are a vulnerable population with complex healthcare needs that are distinct from younger and older age groups. Physical health problems are common in this cohort with communicable diseases being the focus of attention followed by an emphasis on nutritional deficiencies and other chronic disorders. Adolescent refugees have also often experienced multiple traumatic stressors and are at a heightened risk of developing mental health problems. Navigating these problems at the time of pubertal development adds further challenges and can exacerbate or lead to the emergence of health risk behaviours. Educational difficulties and acculturation issues further compound these issues. Adolescents who have had experiences in detention or are unaccompanied by parents are particularly at risk. Despite a constantly growing number of adolescent refugees resettling in high-income countries, knowledge regarding their specific healthcare needs is limited. Research data are largely extrapolated from studies conducted within paediatric and adult cohorts. Holistic management of the medical and psychological issues faced by this group is challenging and requires an awareness of the socioeconomic factors that can have an impact on effective healthcare delivery. Legal and ethical issues can further complicate their management and addressing these in a culturally appropriate manner is essential. Early identification and management of the healthcare issues faced by adolescent refugees resettling in high-income countries are key to improving long-term health outcomes and future healthcare burden. This review article aims to increase knowledge and awareness of these issues among paediatricians and other health professionals.

\section{INTRODUCTION}

Adolescents and young adults comprise a quarter of the world's population, $90 \%$ of whom live in lowincome and middle-income countries. ${ }^{1}$ Persecution, conflict and violence can result in their forced migration into high-income countries (refer to box 1, for important definitions). In 2014, the United Nations High Commissioner for Refugees (UNHCR) estimated that 59.5 million people were forcibly displaced worldwide. ${ }^{2}$ The number of asylum claims lodged in industrialised nations, including USA, Canada, Australasia and Europe continues to rise (approximately 2.8 million from 2010 to 2014). ${ }^{3}$ The ongoing conflict in Syria is fuelling the largest refugee crisis since World War II, prompting international calls for a united global response for high-income countries to resettle larger numbers of refugees.

Approximately half of all refugees are under 18 years of age, although adolescent-specific data (eg, 10-14 and 15-19 years) are not independently collected. ${ }^{2}$ Adolescent refugees have complex medical and psychosocial healthcare needs compounded by socioeconomic vulnerabilities (refer to boxes 2 and 3). The lack of data in the adolescent years is a major limitation when attempting to highlight and improve health outcomes for this group. ${ }^{4}$ Health professionals require an awareness of the specific issues faced by these young people in order to optimise their chances of a successful life in the host country. This review aims to increase the knowledge and training of paediatricians and other health professionals to enable them to provide holistic healthcare for this cohort. For the purpose of this review, adolescents will be considered to be those between 10 and 19 years of age.

\section{Why focus on adolescent health?}

Mortality and morbidity in adolescents largely stems from preventable causes including accidents/ injuries, substance misuse, sexual health diseases and mental health problems in addition to chronic diseases of childhood. ${ }^{1}$ Traumatic experiences in childhood and adolescence can lead to the acquisition of physical, mental and behavioural health problems. ${ }^{5}$ The degree of exposure to traumatic experiences, such as parental separation or death, substance use, neglect or abuse, vicarious or inflicted trauma, has been found to have a cumulative negative impact on health status. Many of these traumatic experiences are common in refugee families. In contrast to the gains in health outcomes for young children globally, adolescent health has improved far less, prompting the need for attention and research. ${ }^{1}$

\section{TRANSIT ISSUES PRIOR TO RESETTLEMENT}

Adolescent refugees encounter multiple and repeated traumatic stressors occurring within three distinct phases of experience, namely 'preflight', 'flight' and 'resettlement'. ${ }^{6}$ The preflight phase may include economic hardship, interrupted education, social upheaval with loss of home and death of family members, exposure to or participation in warfare, political persecution, violence and sexual abuse. During flight, travel through national borders may lead to separation from or death of family members, as well as transition through refugee camps and detention centres.

Poverty, malnutrition, vector exposure, inadequate living conditions and poor health infrastructure augment the risk of developing new health problems and exacerbating existing concerns. ${ }^{6}$ Restricted medical access increases risk of mortality and morbidity, compounded further by psychological or physical trauma. 


\section{Box 1 Definitions}

The 1951 United Nations Convention Relating to the Status of Refugees* defines a refugee as a person who 'owing to well-founded fear of being persecuted for reasons of race, religion, nationality, membership of a particular social group or political opinion, is outside the country of his nationality and is unable or, owing to such fear, is unwilling to avail himself of the protection of that country; or who, not having a nationality and being outside the country of his former habitual residence as a result of such events, is unable or, owing to such fear, is unwilling to return to it'.

An asylum seeker is a person seeking international protection whose claim has not been determined by United Nations High Commissioner for Refugees (UNHCR) or authorities of the country in which refugee status is being requested.

${ }^{*}$ Convention and Protocol relating to the Status of Refugees, Geneva, Switzerland: Office of the UNHCR, Communications and Public Information Service, 1967.

Prior to planned resettlement in high-income countries, refugees undergo a limited predeparture mandatory health screen to detect and treat diseases of public health concern (table 1). ${ }^{78}$ However, this does not apply to those seeking asylum in highincome countries who arrive via alternative routes.

\section{RESETTLEMENT ISSUES}

\section{Physical health}

Postarrival health screening is usually voluntary and guidelines vary internationally. ${ }^{8-10}$ Assessments are largely conducted via centralised refugee health clinics or by general practitioners. Considerable heterogeneity exists across the age spectrum for medical concerns, reflecting epidemiological variation in host countries, ethnic diversity and study sampling. ${ }^{8-11}$

\section{Communicable diseases}

Australasia, USA and Canada have comprehensive internationally published guidelines for the detection of infectious diseases in newly arrived refugees (table 2). ${ }^{8-10}$ Communicable diseases are not specific to adolescent refugees and are therefore not discussed in detail.

Tuberculosis and malaria remain major public health concerns worldwide. Clinical features in adolescents can be a

\section{Box 2 Case vignette 1}

Isaac, a 15-year-old boy of Eritrean ethnicity, resettled in the UK with his four older siblings. His father was killed in conflict and his mother is missing and presumed deceased. The siblings lived in refugee camps for 3 years prior to resettlement.

Schistosomiasis and latent tuberculosis were diagnosed and treated post arrival. The family has been housed and receives governmental financial support. Isaac's oldest sibling is his guardian. Isaac attends high school, plays football in the school team and attends a weekly youth group that has enabled him to make friends. Provision of counselling to deal with the loss of his parents and previous traumatic experiences has improved his mental health. He is optimistic about his future due to the opportunities provided by his host country.

\section{Box 3 Case vignette 2}

Joan is a 16-year-old Dinka-speaking young woman of Sudanese origin who has a 10-month-old son. She was born in a refugee camp in Ethiopia and raised by her maternal grandmother following the death of her parents from infection. She was sponsored for resettlement by a maternal uncle in Australia. Joan became pregnant prior to her departure and has no contact with her partner. Female genital mutilation (FGM) (type 3) was identified during the delivery in Australia. Joan was unaware of her own circumcision and underwent a surgical repair (de-infibulation) post delivery. She has no previous education and rarely attends school, as she needs to care for her son. She has limited English proficiency, financial difficulties and no knowledge of childcare support services. Multiple housing relocations have led to disengagement with the child health nurse and general practitioner. Social isolation, previous physical violence and stigma due to her teenage pregnancy have had a negative impact on her mental health. Many of these issues came to light when her son was admitted to a paediatric hospital and referred to a multidisciplinary refugee health service.

combination of those seen in children and adults. Adolescents with tuberculosis are more likely to present with cavitating disease compared with younger children. ${ }^{12}$ Despite being symptomatic, adolescents may not have identifiable source cases. Adolescents who have lived in areas of high malaria transmission can acquire partial disease immunity over time, modifying disease presentation. ${ }^{13}$ Soil-transmitted helminth infections can cause malnutrition, growth stunting, anaemia and reduced cognitive function in adolescents. ${ }^{14}$ Strongyloides and schistosomiasis have well-established long-term sequelae, including the development of malignancy.

\section{Sexually transmitted infections and blood-borne viruses}

Health professionals should have a low threshold to screen for sexually transmitted infections (STIs) and blood-borne viruses (BBVs) in adolescent refugees. This group has the highest rate of curable STIs worldwide and is the proposed target for preventative control programmes. ${ }^{15}$ If untreated, serious sequelae may result, including infertility, poor obstetric outcomes, neonatal infections and anogenital malignancies. Furthermore, the presence of an STI can increase the risk of transmission and acquisition of HIV.

STI screening in adolescent refugees is not performed routinely. Data regarding the incidence of STIs in those resettling in high-income countries are scarce. This is of particular concern considering the high reports of sexual violence in conflict settings in this cohort. ${ }^{16}$ Evidence suggests that adolescent refugees may continue to be at risk of sexual violence in their host country following resettlement. ${ }^{17}$

Adolescents are at an increased risk of acquiring iatrogenic BBVs in settings of war. ${ }^{18}$ Hepatitis B virus (HBV) is prevalent in adolescent refugees resettling in high-income countries. ${ }^{19}$ Lack of routine testing can result in disease transmission, particularly due to high horizontal infectivity of the virus and relative asymptomatic disease progression. ${ }^{20}$

\section{Reproductive health}

Low levels of sexual health knowledge, limited availability of preventative vaccination (eg, $\mathrm{HBV}$ ) and minimal contraceptive 
Table 1 Predeparture medical assessment (includes all or some of the following). ${ }^{78}$

\begin{tabular}{|c|c|}
\hline Initial medical consultation & History and physical examination, review of immunisation history \\
\hline Chest radiograph & $\geq 11$ years of age \\
\hline Diagnostic tests for TB* & Sputum smear and culture testing \\
\hline Other laboratory investigations & Host-country dependent; eg, HIV/syphilis serology ( $\geq 15$ years), urinalysis \\
\hline Immunisations & Host-country dependent; eg, MMR \\
\hline Detection/presumptive treatment of specific conditions & $\begin{array}{l}\text { Host-country dependent; eg, RDT for malaria (treatment of malaria, if positive) and/or anti-helminth } \\
\text { therapy }\end{array}$ \\
\hline Pre-embarkation 'fitness-to-travel' check & $\begin{array}{l}\text { A rapid assessment } 24-72 \mathrm{~h} \text { before departure to detect new conditions that could compromise the } \\
\text { safety of refugees and other passengers }\end{array}$ \\
\hline $\begin{array}{l}\text { Transfer of relevant health information to appropriate immigration } \\
\text { or public health authorities }\end{array}$ & $\begin{array}{l}\text { Refugees with specific health concerns (eg, TB) sign a Health Undertaking and are required to undergo } \\
\text { medical assessment post arrival to the host country }\end{array}$ \\
\hline
\end{tabular}

*Where abnormal chest radiograph suspicious of TB.

MMR, measles, mumps, rubella vaccination; RDT, rapid diagnostic testing; TB, tuberculosis.

use may contribute to high-risk sexual behaviours increasing the chances of unplanned pregnancy and STIs in adolescent refugees. $^{21}$ Adolescent pregnancy is associated with poor maternal and neonatal outcomes including an increased risk of maternal mortality, neonatal death and preterm delivery. ${ }^{22}$ Cultural taboos and stigma regarding discussions of reproductive health may also complicate health professionals' communication of sensitive topics and need to be factored into education and service delivery. Female genital mutilation (FGM) requires special consideration and is discussed in detail below.

\section{Non-communicable diseases}

Non-communicable diseases (NCDs) affect all age groups and cause high rates of mortality in low-income and middle-income countries, from which most refugee patients arise. $^{23}$ Predeparture and postarrival assessments have traditionally focused on the detection of communicable diseases. Emerging literature demonstrates a high variation of NCDs but adolescent-specific longitudinal data are limited. ${ }^{24} 25$

Congenital and genetic disorders are an important consideration in refugee cohorts and consanguinity needs to be considered. Neurodevelopmental problems, including speech delay, hearing loss and visual impairment, have been reported in refugee adolescents. ${ }^{25}$ Early detection and management can improve quality of life and educational achievement. Increasing migration has resulted in a rising prevalence of haemoglobinopathies in previously low endemic nations. ${ }^{26}$ Early screening in high-risk ethnicities to identify carriers can enable provision of prenatal diagnosis and counselling.

Table 2 Comparative postarrival international infectious diseases and vaccination guidelines for refugees resettling in high-income countries

\begin{tabular}{|c|c|c|c|}
\hline Condition* $†$ & ASID (Australasia) ${ }^{9}$ & $\mathrm{CDC}(\mathrm{USA})^{8}$ & CCIRH (Canada) ${ }^{10}$ \\
\hline Tuberculosis & All & All & $\begin{array}{l}\text { All }<20 \text { years } \\
\text { - } 20-50 \text { years from high incidence } \\
\text { countries }\end{array}$ \\
\hline Malaria & All & $\begin{array}{l}\text { Sub-Saharan African refugees with no } \\
\text { predeparture therapy receive presumptive } \\
\text { treatment/screening }\end{array}$ & Not routine \\
\hline Schistosomiasis & African and South-East Asian refugees & Presumptive treatment/screening if no & African refugees \\
\hline Strongyloides & All & predeparture therapy or symptomatic & African and South-East Asian refugees \\
\hline Other intestinal helminths & $\begin{array}{l}\text { Presumptive treatment/screening if no } \\
\text { predeparture therapy/symptomatic/ } \\
\text { eosinophilia }\end{array}$ & & Not specified \\
\hline HBV & All & $\begin{array}{l}\geq 18 \text { years from countries with moderate/high rate } \\
\text { of chronic } \mathrm{HBV}(\geq 2 \%) \text { and no documentation of } \\
\text { negative } \mathrm{HBsAg} \text { or risk factors present }\end{array}$ & $\begin{array}{l}\text { Refugees from countries with moderate/high } \\
\text { rate of chronic } \mathrm{HBV}(\geq 2 \% \text { positive } \mathrm{HBsAg} \text { ) }\end{array}$ \\
\hline Hepatitis C & All & Anyone with risk factors & $\begin{array}{l}\text { Refugees from countries with a prevalence } \\
\text { of } \geq 3 \%\end{array}$ \\
\hline HIV & All & $\begin{array}{l}\text { 13-64 years, unless they decline } \\
<13 \text { years, unless negative maternal HIV } \\
\text { status }\end{array}$ & $\begin{array}{l}\text { Adolescents and adults from countries with } \\
\text { a prevalence of }>1 \%\end{array}$ \\
\hline Syphilis & All & $\begin{array}{l}\geq 15 \text { years, if no overseas results available } \\
<15 \text { years with risk factors }\end{array}$ & Not routine \\
\hline Chlamydia trachomatis & - All adults & Refugees with symptoms or risk factors & Not routine \\
\hline Neisseria gonorrhoeae & $\begin{array}{l}\text { Youth who are sexually active or may } \\
\text { have been sexually assaulted }\end{array}$ & & \\
\hline Immunisations & $\begin{array}{l}\text { Catch-up regimen according to Australian } \\
\text { Standard Immunisation Schedule }\end{array}$ & $\begin{array}{l}\text { Catch-up regimen according to the Advisory } \\
\text { Committee on Immunization Practices }\end{array}$ & Refugees at risk $\ddagger$ \\
\hline \multicolumn{4}{|c|}{$\begin{array}{l}\text { *Specific investigations/diagnostic algorithms are outlined in the referenced guidelines and will be host-country dependent. } \\
\text { tInformed consent for screening must be undertaken at the time, with use of professional interpreters as required. } \\
\text { \#Vaccination updates for measles, mumps, rubella, polio, diphtheria, tetanus, pertussis, hepatitis B, varicella and human papillomavirus. } \\
\text { ASID, Australasian Society for Infectious Diseases; CDC, Centers for Disease Control and Prevention; CCIRH, Canadian Collaboration for Immigrant and Refugee Health; HBV, Hepatitis B } \\
\text { virus; HBSAg, Hepatitis B surface antigen. }\end{array}$} \\
\hline
\end{tabular}


Poor oral health is common in resettled adolescent refugees. ${ }^{27}$ Parental awareness may be low, highlighting the need for opportunistic assessment by physicians. Multiple cultural and financial barriers can limit access to dental services. ${ }^{28}$

Other NCDs such as hypertension, diabetes and hypercholesterolaemia are prevalent in resettled refugee cohorts. ${ }^{29}$ Modifiable risk factors contributing to their development, including physical inactivity and smoking, commonly begin in adolescence. ${ }^{1}$ Targeted screening, health education and implementation of preventative measures by health physicians is essential.

\section{Nutritional deficiencies}

Refugees commonly experience chronic food shortages in their country of origin that can lead to micronutrient deficiencies and malnutrition, impacting growth and pubertal development in adolescents. ${ }^{3031}$ Food unfamiliarity and change from traditional diets to highly refined foods can also increase the risk of obesity.

Vitamin D deficiency is well described in resettled refugees, with women of childbearing age having the highest risk. ${ }^{32}$ Deficiency can contribute to the development of rickets/osteopenia, metabolic and autoimmune disease, tuberculosis activation, malignancy, neurocognitive dysfunction and infertility. ${ }^{33}$

Iron and vitamin B12 deficiency can result from poor nutrition and from the presence of parasitic infections such as Helicobacter pylori, which impede gut iron absorption, resulting in anaemia. ${ }^{30}$ Other micronutrient deficiencies such as vitamin A, vitamin C, iodine and thiamine have been identified in refugee populations but are not routinely screened for in current guidelines. ${ }^{8} 10$

\section{Psychological health}

Mental health disorders are well recognised among adolescent refugees. ${ }^{6}$ Both risk and protective factors influence outcomes, related to previous trauma and ongoing stressors at the individual, family and community levels. ${ }^{34} 35$ Time postarrival, discrimination, acceptance into the host community, family structure and cohesion, educational difficulties and financial problems modulate responses.

Post-traumatic stress disorder (PTSD) is widely reported in refugees. Multiple traumatic events can augment symptoms and increase predisposition to future distress and dysfunction. ${ }^{36}$ Comorbid mood and anxiety disorders are common. ${ }^{37}$ Those who are subjected to enforced detention are significantly more likely to present with PTSD than those from humanitarian refugee backgrounds and have a heightened suicide risk. ${ }^{38} 39$ There have been reports of violent deliberate self-harm in those exposed to war trauma. ${ }^{40}$

While many adolescent refugees are resilient, there is evidence to suggest that some are prone to develop maladaptive behaviours (violence, aggression, adverse sexualisation and attachment difficulties). ${ }^{37}$ This can potentially hinder adjustment into school and the wider community, further influencing their psychological well-being. There are limited data regarding alcohol and illicit drug use in resettled adolescent refugees. Evidence suggests that violence associated with terrorism and war is positively correlated to mortality and morbidity from substance use disorders. $^{41}$

Poor mental health literacy, cultural stigma towards mental health or traditional healing beliefs may influence refugee families' engagement in appropriate therapy and counselling. ${ }^{42}$ Psychological screening tools may not be culturally appropriate or sensitive, and thus, can fail to identify or underestimate psychological concerns.

\section{Socioeconomic determinants of health}

Language, education and employment issues

Education is a key factor for adolescent refugees resettling in high-income countries. Doctors are ideally placed to highlight the association between education and improved health outcomes and should foster strong links with colleagues in education departments. ${ }^{43}$ School-aged refugees face multiple educational challenges including interrupted schooling and limited primary language literacy. Underlying physical, psychological or developmental problems may complicate performance. Despite this, they have high vocational aspirations and positive attitudes towards educational support in the host country. ${ }^{44} 45$

Establishing fluency in the host language promotes successful resettlement. An insight into second-language acquisition in children suggests that acquiring conversational proficiency is prolonged, and attaining academic language proficiency can take at least 5 years. ${ }^{46}$ Adolescents integrating into high schools have access to fewer years of schooling and may therefore not achieve their full educational potential. ${ }^{44}$ Older adolescents may be at the limit of school enrolment age. Incomplete documentation of prior education may hinder entry to higher education or employment, as may financial restraints or lack of appropriate guidance regarding further education options. ${ }^{45}$ Unfamiliarity with information technology and limited internet access can be problematic, particularly when searching for employment.

Evidence suggests an inverse relationship between adolescents' academic achievement and engagement in health risk behaviours. ${ }^{47}$ Academic and behavioural problems in the school environment have been identified in adolescent refugees who have experienced traumatic events. ${ }^{37}$ Positively perceived school performance promotes physical and psychosocial well-being. ${ }^{34}$

Data regarding long-term academic achievement and subsequent employment outcomes in resettled adolescent refugees are limited. This is an important area of concern, particularly examining outcomes following transition from intensive schooling support to more mainstream education services. Evidence from immigrant populations suggests that a younger age of migration is associated with enhanced host language proficiency and employment outcomes. ${ }^{48}$

\section{Healthcare barriers}

Resettled adolescent refugees are positive regarding better availability of medical care in high-income countries although they encounter barriers to accessing healthcare. ${ }^{44}$ Language and cultural barriers, poor health literacy, unfamiliarity with healthcare systems, transport or financial difficulties and alternate priorities such as employment and housing are common. ${ }^{49}$

Use of primary healthcare services by adolescent refugees is minimal. ${ }^{50}$ Many have had no previous immunisations or are under-immunised and remain at risk of developing vaccine preventable diseases. For adolescents requiring tertiary healthcare, barriers to effective transition from paediatric to adult services pose further challenges and can have a negative impact on healthcare delivery. ${ }^{51}$ Empowering adolescents to seek healthcare independently, as recommended by advocates of adolescent health, may also lead to conflict with parents within some cultural settings, and so needs to be managed sensitively.

\section{Acculturation issues}

Acculturation describes the process of adapting the cultural traits of another group. Differing rates of acculturation between parents and adolescents during the resettlement period can create intrafamilial conflict, with adolescents torn between their 
own or host culture. Adolescents often acquire host language proficiency faster than their parents and may be required to support them in conducting daily activities, leading parents to feel disempowered. ${ }^{44}$ Differences between cultural parenting practices and host country laws may lead to involvement of child protection agencies, diminishing parental authority. ${ }^{52}$ In contrast, overcoming previous family struggles during their refugee journey may encourage family cohesion promoted by the safety of the host country. ${ }^{44}$

Strong peer relationships positively impact the long-term well-being of refugees, while experiences of discrimination and school bullying can hinder assimilation. ${ }^{34} 53$ Many adolescents express loneliness from being separated from friends in their home country. ${ }^{45}$ Participation in religious and cultural activities with those from similar backgrounds is common, but interaction outside this network often remains limited. ${ }^{44}$ Boys commonly socialise through sporting activities, which are limited in girls who may struggle to form peer relationships. Availability of free public transport can facilitate participation in social activities, however procedural and financial difficulties associated with acquiring a driver's license can be cumbersome. $^{44} 45$

Despite several acculturative stressors, adolescent refugees have been reported to have high future expectations and to be optimistic and grateful for new opportunities provided by the host country. ${ }^{44} 4553$ Awareness of acculturation issues by healthcare providers is important to optimise engagement of the adolescent and their family.

\section{Child maltreatment and child protection issues}

There have been reports of increased rates of child and adolescent maltreatment in resettled refugee cohorts, including physical, sexual and emotional abuse as well as neglect. ${ }^{545}$ Poverty, intergenerational acculturation issues as well as parental factors such as mental health problems, substance use, illiteracy and unemployment compound these concerns.

Many adolescent refugees resettling in high-income countries originate from regions where child marriage is commonly practised. ${ }^{56}$ Social isolation, illiteracy, limited health education, exposure to sexual violence and adolescent pregnancy increase their vulnerability. Reports suggest that war, conflict and forced migration exacerbate the risk of child marriage. ${ }^{57}$ Although child marriage is illegal in many high-income countries, there are reports that it still continues to be practised, reinforced by the lack of open reporting pathways. ${ }^{58}$

FGM is practised extensively worldwide, affecting over 125 million girls and is traditionally undertaken before the age of 15 years. ${ }^{59}$ While illegal in many countries, female refugees may have undergone procedures prior to resettlement or remain at risk following resettlement due to cultural expectations. ${ }^{60}$ There has been increasing consensus to collect data in many host countries to provide better prevalence estimates. FGM has several immediate and long-term health sequelae, including sterility, recurrent urinary tract infection, poor obstetric outcomes and death, highlighting the need to identify those with completed FGM so that appropriate gynaecological review can be sought. Psychological problems resulting from the practice have also been described. Many women are unaware of their own circumcision or 'normal female anatomy'. Conversations should be sensitive and standardised to avoid stigmatising ethnic groups. For girls at high-risk of FGM, appropriate medical and legal counselling and education should be provided to the adolescent and their family, in line with relevant child protection legislation.

\section{Specific groups}

Increased awareness of the additional difficulties faced by adolescent refugees, who are unaccompanied minors, separated from family or have experienced detention, can allow health professionals to screen and manage issues appropriately.

The number of unaccompanied minors seeking asylum in high-income countries continues to rise (34 300 applications in 2014), the majority being adolescents. ${ }^{2} 61$ Compared with those accompanied by parents, unaccompanied adolescents are more likely to have experienced higher rates of traumatic events in their country of origin and have been found to have more mental health problems, including depression and post-traumatic stress. ${ }^{62}$ Provision of adequate social support and education improves mental health and successful long-term resettlement.

Nuclear family separation can impede successful resettlement and have a negative impact on the mental health of refugees. ${ }^{63}$ Family reunification can help alleviate stressors. However, the process is complex, prolonged and can result in family conflict when old relationships re-establish after prolonged periods. Family separation and parental death may lead to adolescents adapting parental roles for younger siblings. Recognition of these roles can enable physicians to provide adequate emotional and social support.

International concern continues regarding the mandatory detention of refugees and asylum seekers. Detention for any length of time has been reported to have detrimental effects on mental, physical, behavioural and developmental health, which can persist following release. ${ }^{64}$ In adolescents, detention increases the risk of self-harm and suicide and impedes social and emotional maturation. The lack of education in detention facilities deters cognitive development and academic achievement. Reports of abuse, including the sexual abuse of children and adolescents in detention, have raised significant child protection concerns in high-income nations. Medical organisations such as the Royal Australasian College of Physicians have called for the

Box 4 Suggested recommendations for health professionals for the assessment and management of adolescent refugees

1. Introduce the use of a standardised refugee health assessment to include sociodemographic details: transit journey (countries, periods in refugee camps and detention), language, family structure, education history and risk factors for child protection concerns (early maternal age of marriage and circumcision). (Refer to online supplementary appendix 1.)

2. Explore broader aspects of adolescent health (physical, developmental, behavioural, educational and health-risk issues) during initial and ongoing assessments.

3. Develop strong links with colleagues in agencies involved in providing support to adolescent refugees (primary care, tertiary hospitals, social services, educational agencies, governmental bodies).

4. Highlight and advocate for the need to collect health data based on 5 year age-bands (10-14, 15-19, 20-24 years).

5. Make use of available resources for education and training to improve knowledge regarding key challenges encountered in adolescents from a refugee background, specifically acculturation stressors, mental health risks, interrupted education and common physical health concerns. 
immediate release of all those in immigration detention. ${ }^{11}$ UNHCR has launched an initiative aimed at helping countries move away from immigration detention with a goal to end the detention of children and adolescents worldwide by $2019 .{ }^{65}$

\section{RECOMMENDATIONS AND CONCLUSION}

There are recommended frameworks for good practice that highlight models of effective healthcare provision for refugee children. ${ }^{66}$ However, issues that encompass the specific healthcare needs of adolescents should be incorporated into consultations to help improve long-term outcomes in this vulnerable cohort. Suggestions for clinicians are outlined in box 4 .

Many refugees are highly resilient and make significant contributions to society, which need recognition. As highlighted by a number of international organisations, including the WHO, the World Bank and United Nations Children's Fund, improving the health of today's adolescents is fundamental to securing the health of tomorrow's adults.

Contributors DP and SC contributed to the conception of the review theme. Al authors have contributed towards literature review, manuscript preparation and revision.

Funding $\mathrm{KH}$ is the recipient of a 2014 Princess Margaret Hospital Foundation Seeding Grant (Grant ID number: 9546).

Competing interests None declared.

Provenance and peer review Commissioned; externally peer reviewed.

\section{REFERENCES}

1 Sawyer SM, Afifi RA, Bearinger LH, et al. Adolescence: a foundation for future health. Lancet 2012;379:1630-40.

2 UNHCR Publications. UNHCR Global Trends 2014: World at War, 2015. http:/l unhcr.org/556725e69.html (accessed Aug 2015).

3 UNHCR Publications. UNHCR Asylum Trends 2014: Levels and Trends in Industrialized Countries; 2015. http://www.unhcr.org/551128679.html (accessed Aug 2015).

4 Payne D. Meeting the needs of young people in hospital. Arch Dis Child 2013;98:930-2.

5 Felitti VJ, Anda RF, Nordenberg D, et al. Relationship of childhood abuse and household dysfunction to many of the leading causes of death in adults. The Adverse Childhood Experiences (ACE) Study. Am J Prev Med 1998;14:245-58.

6 Lustig SL, Kia-Keating M, Knight WG, et al. Review of child and adolescent refugee mental health. J Am Acad Child Adolesc Psychiatry 2004;43:24-36.

7 International Organization for Migration. Essentials of Migration Management for Policy Makers and Practitioners; Volume 2: Developing Migration Policy, 2004. http:// www.rcmvs.org/documentos/IOM_EMM/v2/V2S07 CM.pdf (accessed Apr 2015).

8 Centers for Disease Control and Prevention. Refugee Health Guidelines. Guidelines for pre-departure and post-arrival medical screening and treatment of US-bound refugees. Last updated November 2013. http://www.cdc.gov/immigrantrefugee health/guidelines/refugee-guidelines.html (accessed Feb 2015).

9 The Australasian Society for Infectious Diseases. Clinical guidelines. Diagnosis, management and prevention of infections in recently arrived refugees, 2009. https:/l www.asid.net.au/documents/item/134 (accessed Jan 2015).

10 Pottie K, Greenaway C, Feightner J, et al. Evidence-based clinical guidelines for immigrants and refugees. CMAJ 2011;183:E824-925.

11 The Royal Australasian College of Physicians. Policy on Refugee and Asylum Seeker Health, 2015. https://members.racp.edu.au/page/asylum-seekers (accessed May 2015)

12 Cruz AT, Hwang KM, Birnbaum GD, et al. Adolescents with tuberculosis: a review of 145 cases. Pediatr Infect Dis J 2013:32:937-41.

13 Laishram DD, Sutton PL, Nanda N, et al. The complexities of malaria disease manifestations with a focus on asymptomatic malaria. Malar J 2012;11:29.

14 Norman FF, Monge-Maillo B, Martinez-Perez A, et al. Parasitic infections in travelers and immigrants: part II helminths and ectoparasites. Future Microbiol 2015; 10:87-99.

15 Gottlieb SL, Low N, Newman LM, et al. Toward global prevention of sexually transmitted infections (STIs): the need for STI vaccines. Vaccine 2014;32:1527-35.

16 Marsh M, Purdin S, Navani S. Addressing sexual violence in humanitarian emergencies. Glob Public Health 2006;1:133-46.

17 Keygnaert I, Vettenburg N, Temmerman M. Hidden violence is silent rape: sexual and gender-based violence in refugees, asylum seekers and undocumented migrants in Belgium and the Netherlands. Cult Health Sex 2012;14:505-20.
18 Goldwater PN. latrogenic blood-borne viral infections in refugee children from war and transition zones. Emerg Infect Dis 2013;19(6). doi:10.3201/eid1906.120806 (accessed May 2015).

19 Museru Ol, Vargas M, Kinyua $M$, et al. Hepatitis B virus infection among refugees resettled in the US: high prevalence and challenges in access to health care. J Immigr Minor Health 2010;12:823-7.

20 Hurie MB, Mast EE, Davis JP. Horizontal transmission of hepatitis B virus infection to United States-born children of Hmong refugees. Pediatrics 1992;89:269-73.

21 McMichael C, Gifford S. Narratives of sexual health risk and protection amongst young people from refugee backgrounds in Melbourne, Australia. Cult Health Sex 2010:12:263-77.

22 Jeha $D$, Usta I, Ghulmiyyah $L$, et al. A review of the risks and consequences of adolescent pregnancy. J Neonatal Perinatal Med. 2015. Published Online First: 12 March 2015

23 Abegunde DO, Mathers CD, Adam T, et al. The burden and costs of chronic diseases in low-income and middle-income countries. Lancet 2007;370:1929-38.

24 Mutch RC, Cherian S, Nemba K, et al. Tertiary paediatric refugee health clinic in Western Australia: analysis of the first 1026 children. J Paediatr Child Health 2012:48:582-7.

25 Watts DJ, Friedman JF, Vivier PM, et al. Health care utilization of refugee children after resettlement. J Immigr Minor Health 2012;14:583-8.

26 Aguilar Martinez P, Angastiniotis M, Eleftheriou A, et al. Haemoglobinopathies in Europe: health \& migration policy perspectives. Orphanet J Rare Dis 2014;9:97.

27 Quach A, Laemmle-Ruff IL, Polizzi T, et al. Gaps in smiles and services: a cross-sectional study of dental caries in refugee-background children. BMC Oral Health 2015:15:10.

28 Davidson N, Skull S, Calache $H$, et al. Equitable access to dental care for an at-risk group: a review of services for Australian refugees. Aust N Z J Public Health 2007;31:73-80

29 Yun K, Hebrank K, Graber LK, et al. High prevalence of chronic non-communicable conditions among adult refugees: implications for practice and policy. J Community Health 2012:37:1110-8.

30 Fabio M. Nutrition for refugee children: risks, screening, and treatment. Curr Probl Pediatr Adolesc Health Care 2014;44:188-95.

31 Soliman A, De Sanctis V, Elalaily R. Nutrition and pubertal development. Indian J Endocrinol Metab 2014;18:S39-47.

32 Aucoin $\mathrm{M}$, Weaver $\mathrm{R}$, Thomas $\mathrm{R}$, et al. Vitamin $\mathrm{D}$ status of refugees arriving in Canada: findings from the Calgary Refugee Health Program. Can Fam Physician 2013;59:e188-194

33 Pludowski P, Holick MF, Pilz S, et al. Vitamin D effects on musculoskeletal health, immunity, autoimmunity, cardiovascular disease, cancer, fertility, pregnancy, dementia and mortality-a review of recent evidence. Autoimmun Rev 2013;12:976-89.

34 Correa-Velez I, Gifford SM, Barnett AG. Longing to belong: social inclusion and wellbeing among youth with refugee backgrounds in the first three years in Melbourne, Australia. Soc Sci Med 2010:71:1399-408.

35 Fazel M, Reed RV, Panter-Brick C, et al. Mental health of displaced and refugee children resettled in high-income countries: risk and protective factors. Lancet 2012;379:266-82.

36 Mghir R, Freed W, Raskin A, et al. Depression and posttraumatic stress disorder among a community sample of adolescent and young adult Afghan refugees. J Nerv Ment Dis 1995:183:24-30.

37 Betancourt TS, Newnham EA, Layne CM, et al. Trauma history and psychopathology in war-affected refugee children referred for trauma-related mental health services in the United States. J Trauma Stress 2012;25:682-90.

38 Francis JR, Cherian S, Forbes D. Seeking asylum: health and human rights in Australia. MJA 2013;122:99-100.

39 McNamara PM. Adolescent suicide in Australia: rates, risk and resilience. Clin Child Psychol Psychiatry 2013:18:351-69.

40 Patel N, Hodes M. Violent deliberate self-harm amongst adolescent refugees. Eur Child Adolesc Psychiatry 2006;15:367-70.

41 Kerridge BT, Khan MR, Rehm J, et al. Terrorism, civil war and related violence and substance use disorder morbidity and mortality: a global analysis. J Epidemiol Glob Health 2014:4:61-72.

42 Colucci E, Minas H, Szwarc J, et al. In or out? Barriers and facilitators to refugeebackground young people accessing mental health services. Transcult Psychiatry 2015. Published Online First: 2 Mar 2015.

43 Mace AO, Mulheron S, Jones $C$, et al. Educational, developmental and psychological outcomes of resettled refugee children in Western Australia: a review of School of Special Educational Needs: Medical and Mental Health input. J Paediatr Child Health 2014;50:985-92.

44 Earnest J, Mansi R, Bayati $\mathrm{S}$, et al. Resettlement experiences and resilience in refugee youth in Perth, Western Australia. BMC Res Notes 2015;8:236.

45 Earnest J. Adolescent and young refugee perspectives on psychosocial well-being. IJH 2005:3:79-86.

46 Clifford V, Rhodes A, Paxton G. Learning difficulties or learning English difficulties? Additional language acquisition: an update for paediatricians. J Paediatr Child Health 2014;50:175-81. 
47 Bradley BJ, Greene AC. Do health and education agencies in the United States share responsibility for academic achievement and health? A review of 25 years of evidence about the relationship of adolescents' academic achievement and health behaviors. J Adolesc Health 2013;52:523-32.

48 Guven C, Islam A. Age at migration, language proficiency, and socioeconomic outcomes: evidence from Australia. Demography 2015;52:513-42.

49 Sheikh-Mohammed M, Macintyre CR, Wood NJ, et al. Barriers to access to health care for newly resettled sub-Saharan refugees in Australia. Med J Aust 2006;185:594-7.

50 Thomas P, Milne B, Raman S, et al. Refugee youth-immunisation status and GP attendance. Aust Fam Physician 2007;36:568-70.

51 Viner RM. Transition of care from paediatric to adult services: one part of improved health services for adolescents. Arch Dis Child 2008;93:160-3.

52 Lewig K, Arney F, Salveron M. Challenges to parenting in a new culture: implications for child and family welfare. Eval Program Plann 2010;33:324-32.

53 Caxaj CS, Berman H. Belonging among newcomer youths: intersecting experiences of inclusion and exclusion. ANS Adv Nurs Sci 2010;33:E17-30.

54 Euser EM, Van ljzendoorn MH, Prinzie $\mathrm{P}$, et al. Elevated child maltreatment rates in immigrant families and the role of socioeconomic differences. Child Maltreat 2011;16:63-73.

55 Chang J, Rhee S, Berthold SM. Child abuse and neglect in Cambodian refugee families: characteristics and implications for practice. Child Welfare 2008;87:141-60.

56 UNICEF Resources. Ending Child Marriage: Progress and Prospects, 2014. http:/l www.data.unicef.org/resources/ending-child-marriage-progress-and-prospects (accessed May 2015).

57 Save the Children Report. Too Young to Wed: The growing problem of child marriage among Syrian girls in Jordan, 2014. https://www.savethechildren.org. au/_data/assets/pdf_file/0008/53945/too_young-too-wed.pdf (accessed May 2015).

58 Plan International Australia. Just married, Just a child: Child marriage in the Indo-Pacific region; 2014. https://www.plan.org.au/Learn/Research-and-Reports.aspx (accessed Apr 2015)

59 UNICEF Publications. Female Genital Mutilation/Cutting: A statistical overview and exploration of the dynamics of change. 2013. http://www.unicef.org/publications/ index_69875.html (accessed Apr 2015).

60 Creighton SM, Hodes D. Female genital mutilation: what every paediatrician should know. Arch Dis Child 2016;101:212-6.

61 European Migration Network. Policies, practices and data on unaccompanied minors in the EU Member States and Norway: EMN Synthesis Report, 2015. http://emn.ie/ cat_publication_detail.jsp?clog=1\&itemID=2864\&t=6 (accessed Sep 2015).

62 Eide K, Hjern A. Unaccompanied refugee children-vulnerability and agency. Acta Paediatr 2013;102:666-8.

63 Choummanivonga C, Poole GE, Cooper A. Refugee family reunification and mental health in resettlement. N Z J Soc Sci Online 2014;9:89-100.

64 Australian Human Rights Commission Publication. The Forgotten Children: National Inquiry into Children in Immigration Detention (2014), 2015. https://www. humanrights.gov.au/our-work/asylum-seekers-and-refugees/publications/ forgotten-children-national-inquiry-children (accessed May 2015).

65 UNHCR Publication. Beyond Detention: A Global Strategy to support governments to end the detention of asylum-seekers and refugees. 2014. http://www.unhcr.org/ 53aa929f6.html (accessed Apr 2015).

66 Woodland L, Burgner D, Paxton G, et al. Health service delivery for newly arrived refugee children: a framework for good practice. J Paediatr Child Health 2010;46:560-7. 